\title{
Secondary School Teachers' Perceptions of Assessment
}

\author{
Joyce L. Ndalichako
}

\begin{abstract}
Assessment is a vital instrument for enhancing teaching and learning. Perceptions that teachers have on assessment are likely to influence their assessment practices. This study explored perceptions of secondary school teachers on assessment. A total of 4160 Tanzanian teachers were involved in the study. A questionnaire comprising questions that sought to establish demographic information of participants as well as their perceptions on assessment was used. Results show that 50.7 percent of the teachers who participated in the study considered the purpose of assessment is to make decisions on teaching and learning. Perceptions on assessment show that items on the role of assessment in making students concentrate their efforts in learning, making students confident in their final examination and usefulness of feedback in enhancing students' performance were strongly agreed or agreed by a large proportion of the participants.
\end{abstract}

Index Terms-Assessment practices, classroom assessment, learning outcomes, perceptions of teachers.

\section{INTRODUCTION}

Assessment refers to the methods used in determining the extent to which students are achieving the intended learning outcomes for a particular course or programme [1], [2]. Assessment is an integral part of teaching and learning which involves the process of gathering, interpreting and recording information related to student progress in learning and the effectiveness of the teaching strategies [3]. It aims at bringing about improvement for both the teacher who is assessing and the students who are being assessed. According to Popham [4], assessment enables teachers to gather information about the students' progress as well as the extent to which methods of instruction used are helping the students to achieve the intended learning outcomes. Through assessment teachers can explore better ways of supporting students' learning and regulating their teaching strategies. On the other hand, assessment helps the students to know the areas that they need to work hard so as to attain the desirable learning outcomes.

Assessment is used to improve both teaching and learning and is crucial in ensuring the quality of education offered. Assessment can contribute to enhancing quality of education if appropriate decisions and measures are taken based on the information revealed through assessment. However, determining what to assess and how to assess effectively and establishing remedial measures required, is a complex process. Other scholars view assessment as an essential tool for engaging students in learning as well as for sustaining their commitment and efforts to study [5], [6]. Students tend

Manuscript received March 20, 2014; revised May 20, 2014.

J. L. Ndalichako is with the Aga Khan University, Institute for Educational Development, East Africa (e-mail: joyce.ndalichako@aku.edu). to concentrate and pay keen attention to their studies if they know that at the end of topic they will be assessed. Their commitment tends to correlate highly with the stakes associated with the decisions to be made based on assessment they undertake. For instance, when promotion to the next class depends on attaining a certain pass mark score, they will tend to take studies more seriously than they would if the scores were to be used only for reporting purposes. Assessment plays an important role in motivating students' learning and in formation of good study habits. Encouragement and reward of individual efforts would have been difficult if there was no assessment and excellence in achievement would be less demonstrable [6].

\section{ROLE OF ClasSROOM ASSESSMENT}

Classroom assessment is seen as a vital ingredient for effective teaching and learning. It is essential because it gives students guidance on their performance and contributes to improving the learning process [4], [7]. Classroom assessment provides feedback on students' progress over a period of time so that any errors or learning difficulties can be identified and corrected. Research evidence show that classroom assessment is a fundamental aspect of the teaching and learning process, and that when it is integrated in classroom practices substantial learning gains can be achieved [8], [9]. Due to the powerful influence of assessment on learning outcomes, researchers have advocated for the integration of assessment with teaching and learning [9], [10]. The role of teachers in ensuring that assessment leads to effective teaching and learning cannot be over-emphasized. Teachers are expected to play a dual-role of facilitating students' learning and of implementing classroom assessment in a manner that will enhance meaningful learning outcomes. Their role in assessment encompasses the whole process of constructing and administering of assessment tasks to interpreting the results generated from assessment.

It is well documented that assessment has a great influence in teaching and learning [11], [12]. The desire to ensure alignment of assessment with teaching and learning process has led to a growing interest to investigate teachers' perceptions of assessment and their assessment practices and skills. The purpose of this study was to explore perceptions of secondary school teachers in Tanzania on assessment. Studying teachers' perceptions of assessment is important due to the fact that perceptions affect behavior [13], [14]. Thus the study was designed to investigate the perceptions of assessment held by secondary school teachers in Tanzania. The significance of the study lies on the fact that perceptions of teachers on assessment have implications on how assessment is implemented and on the use the information 
generated to enhance teaching and learning. In emphasizing the importance of perceptions, [15], [16] observed that although teachers are trained to develop sound and valid assessment measures, their perceptions and beliefs may affect the way they teach and assess their students.

\section{The CONTEXT OF THE STUDY}

The education system in Tanzania consists of three major cycles: primary, secondary and tertiary education. The system is centralised where all schools use the same curriculum developed by the Tanzania Institute of Education. The system is also highly examination-oriented with emphasis on outstanding passing of examinations to enable examinees secure admission into reputable schools or colleges. Secondary examinations are high-stakes because success in secondary examination is regarded as a gate pass to a number of opportunities such as continuation to the advanced level of secondary education or enrolment into professional training colleges such as teacher education, nursing, agricultural and business. Moreover, in order to secure any kind of employment in the public sector, one must possess the Certificate of Secondary Education. Hence, the results of the Certificate of Secondary Education Examination (CSEE) have significant consequences in determining both the education and life pathways of the students. Results show that there has been a declining trend in performance of students in CSEE as shown in Fig. 1.

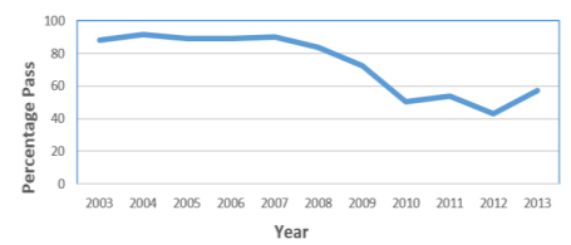

Fig. 1. Performance of students in CSEE for 2003 - 2013.

The declining performance has fuelled a lot pressure among the students, teachers, parents and the entire public. Possible explanations are put forward in search for the reasons for declining performance. Teachers are blamed for not teaching effectively whereas students are blamed for not being serious with their studies. On the other hand, parents are blamed for not making follow-up on what their children are doing in schools whereas the government is blamed for not providing sufficient teaching and learning facilities in schools. Indeed, there is a blame-game as each stakeholder is pointing a finger to another stakeholder. Due to the prevailing circumstances, there is a great deal of pressure to ensure that the declining trend in performance is reversed. In an attempt to curb the situation, the "Big Results Now" initiative was launched and is being implemented, which among other strategies frequent testing of students is seen as a means to prepare them to undertake their final examination confidently.

\section{METHOD OF THE STUDY}

\section{A. Objectives of Study}

The study major purpose of the study was explore secondary school teachers' perceptions of assessment. The study intended to achieve the following objectives:

- To establish teachers' perceptions of assessment.

- To determine whether there are significant differences in teachers' perceptions of assessment by gender.

\section{B. Instruments}

The questionnaire developed by the researcher was used. It consisted of items concerning the demographic information of the participants and items concerning teachers' perception of assessment. A five point likert-scale was used. Participants were asked to indicate their levels of agreement with statements in such a way that 5 reflected strongly agree (SA), 4 - agree (A), 3 - undecided (U), 2 - disagree (D) and 1 strongly disagree (SD). The draft questionnaire was reviewed by five experts. Based on their comments, the questionnaire was reviewed and finalized.

\section{Participants and Data Analysis}

The study involved teachers who participated in marking of CSEE 2013. The marking exercise comprises of teachers from all the regions in the country. It was therefore considered that the views of the teachers who participated in marking would be a representation of the perceptions of teachers in general. A total of 4330 teachers who were requested to participate in the study and the questionnaires were given to them. Returned completed questionnaires were 4160. There were some few items that were skipped by respondents as no responses were provided. Data were coded accordingly and entered SPSS programme for analysis. Both descriptive statistics such as means and standard deviations as well as inferential statistics, t-test for independent samples were used.

\section{Results OF THE STUdy}

\section{A. Demographic Characteristics of Participants}

The demographic information of participants were analysed to reveal the characteristics of teachers who participated in the study. Fig. 2 indicates the composition of participants by gender.

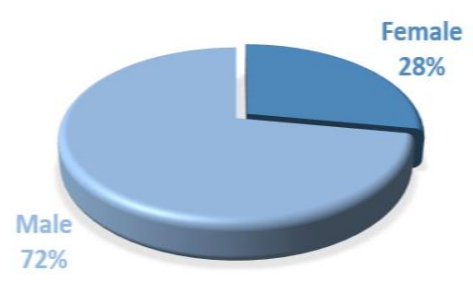

Fig. 2. Composition of participants by sex.

As shown in Fig. 2, male teachers comprised of 72 percent whereas female teachers comprised of only 28 percent of the participants.

Teaching experience of the participants as measured by the years of teaching, in categories, are presented in Table I. Table I shows that 43.8 percent of teachers who participated in the study had teaching experience of 6-10 years whereas 23.9 percent had teaching experience of less than five years. Highly experienced teachers (veterans) who have taught for more than 20 years comprised 9.3 percent of the participants. 
Teachers who taught for a period of 11-15 years consisted of 15.2 percent of the participants whereas only 7.3 percent had teaching experience of 16-20 years.

TABLE I: COMPOSITION OF PARTICIPANTS BY TEACHING EXPERIENCE

\begin{tabular}{lcccc}
\hline Experience & Female & Male & Total & Percent \\
\hline Less than 5 years & 261 & 709 & 970 & 23.9 \\
6-10 Years & 415 & 1365 & 1780 & 43.8 \\
11-15 years & 214 & 403 & 617 & 15.2 \\
16-20 years & 114 & 204 & 318 & 7.8 \\
More than 20 Years & 122 & 256 & 378 & 9.3 \\
Total & 1126 & 2937 & 4063 & 100.0 \\
\hline \hline
\end{tabular}

The age composition of the participants are presented in Fig. 3.

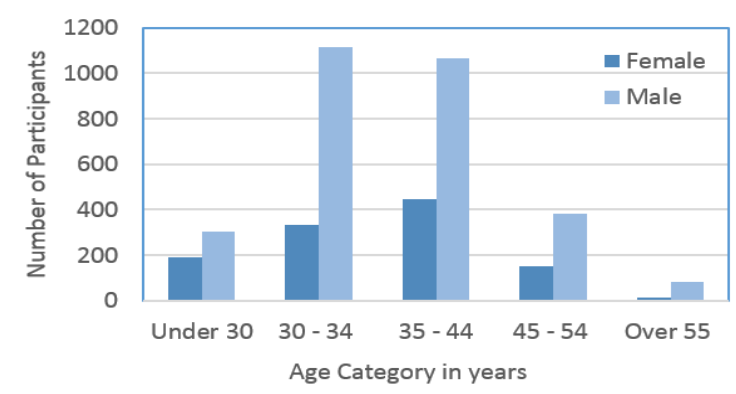

Fig. 3. Composition of participants by age category.

Fig. 3 indicates that most of the teachers $(37.0 \%)$ who participated in the study had 30-44 years of age whereas 35.5 percent were of age 30-34 years. Only 2.4 percent of teachers were over 55 years of age.

\section{B. Perceived Purpose of Assessment}

The study intended to explore teachers' perception of the purpose of conducting assessment in their classrooms. A closed question was used and teachers were asked to select only one response that mostly reflected their reason for assessing students. The responses of the teachers are provided in Table II.

TABLE II: TEACHERS' VIEWS ON THE PURPOSE OF ASSESSMENT

\begin{tabular}{lcc}
\hline \hline Purpose of Assessment & Frequency & Percent \\
\hline To assign marks/grades to students & 257 & 6.4 \\
To prepare students for their final examination & 832 & 20.7 \\
To promote students to other classes & 134 & 3.3 \\
To rank students at the end of each term & 156 & 3.9 \\
To make decisions on teaching and learning & 2047 & 50.9 \\
To enhance concentration of students in class & 534 & 13.3 \\
To generate marks for reporting purposes & 60 & 1.5 \\
\hline \hline
\end{tabular}

Table II shows that half of the teachers (50.9\%) selected the purpose of assessment as to make decisions related to teaching and learning. This implies that those teachers consider assessment as an essential tool in guiding them in terms of what to teach next and how to teach. This finding is consistent with [2], [12] who contended that classroom assessment should provide feedback to modify the teaching and learning process. On the other hand, 20.7 percent of the teachers considered the purpose of assessment as to prepare students for their final examination. This view of the purpose of assessment reflects a conflict that teachers are having on whether they should channel their energy in enhancing learning outcomes or they should focus on preparing students for examinations. As indicated in the context of the study, the pressure to increase pass rates in secondary examinations is enormous. Thus, using assessment to improve classroom instruction is not as important as it is to increase pass rates in the final examination.

A small percentage of teachers $(6.4 \%)$ considered the purpose of assessment as to assign marks or grades to students. In this regard teachers were mainly concerned with the accountability function of assessment. If it was not a requirement for them to generate and report marks and grades, assessment would not have been necessary to them. Teachers who indicated that the purpose of assessment is to enhance concentration of students $(13.3 \%)$ viewed assessment from a motivational perspective. It a common practice for students to concentrate more on a topic if they know that they will be assessed than if they know that they will not be assessed. Thus teachers who indicated that assessment helps students to concentrate on their studies held motivational function of assessment highly.

\section{Teachers' Perceptions of Assessment}

Teachers' perceptions of assessment were measured using a 5-point likert-scale. Teachers were asked to indicate their levels of agreement to various statements that they were given regarding assessment. The means and standard deviations of their responses on each of the perception statements are presented in Table III.

TABLE III: MEANS AND STANDARD DEVIATIONS OF PERCEPTIONS

\begin{tabular}{llll}
\hline \hline & $\mathrm{N}$ & Mean & $\begin{array}{l}\text { Std. } \\
\text { Deviation }\end{array}$ \\
\hline $\begin{array}{l}\text { Assessment makes students concentrate } \\
\text { their efforts in learning }\end{array}$ & 4087 & 4.459 & 0.776 \\
$\begin{array}{l}\text { Assessment makes students attentive in the } \\
\text { classroom }\end{array}$ & 4082 & 4.243 & 0.844 \\
$\begin{array}{l}\text { Assessment makes students confident for } \\
\text { their final examination }\end{array}$ & 4083 & 4.430 & 0.859 \\
$\begin{array}{l}\text { Assessment makes it difficult for teachers } \\
\text { to cover the syllabus }\end{array}$ & 4077 & 2.174 & 1.233 \\
$\begin{array}{l}\text { Assessment has negligible impact on } \\
\text { teaching and learning }\end{array}$ & 4073 & 2.108 & 1.302 \\
$\begin{array}{l}\text { Assessment feedback is useful in } \\
\text { enhancing students' performance }\end{array}$ & 4081 & 4.444 & 0.854 \\
$\begin{array}{l}\text { Assessment increases the workload for } \\
\text { teachers }\end{array}$ & 4067 & 2.992 & 1.421 \\
$\begin{array}{l}\text { Assessment should be conducted based on } \\
\text { students' time }\end{array}$ & 4075 & 2.582 & 1.330 \\
$\begin{array}{l}\text { Assessment should be conducted based on } \\
\text { teachers convenience }\end{array}$ & 4053 & 2.813 & 1.286 \\
\hline \hline
\end{tabular}

Table III shows that teachers had highly favorable perceptions of the role of assessment in making students: concentrate their efforts in learning (Mean $=4.459, \mathrm{~S} . \mathrm{D}=$ 0.776 ), attentive in the classroom (Mean $=4.243$, S.D $=$ 0.844 ), and confident in their final examinations (Mean $=$ 4.430 , S.D $=0.859$ ). Their perception on a statement that assessment feedback is useful in enhancing students, performance was favorably high with a mean of 4.444 and 
standard deviation of 0.854 . Statements that assessment increases the workload of teachers had a mean of 2.992 and standard deviation of 1.421 and that assessment should be conducted based on teachers convenience (Mean $=2.813$, S.D $=1.286$ ) was agreed by a considerable proportion of teachers as reflected by their respective means. Teachers with such views tend to consider assessment as a burden for them rather than an important tool which generates useful information for enhancing both teaching and learning.

The percentages of responses given by respondents for each of the perception statements contained in the questionnaire are presented in Table IV.

TABLE IV: TEACHERS' PERCEPTIONS OF ASSESSMENT

\begin{tabular}{|c|c|c|c|c|c|c|}
\hline \multirow[b]{2}{*}{ Perception on assessment } & \multicolumn{6}{|c|}{ Level of Agreement in $\%$} \\
\hline & $\mathrm{N}$ & $\begin{array}{l}\text { Strongly } \\
\text { Disagree }\end{array}$ & Disagree & Undecided & Agree & $\begin{array}{l}\text { Strongly } \\
\text { Agree }\end{array}$ \\
\hline Assessment makes students concentrate their efforts in learning & 4087 & 1.9 & 1.4 & 2.4 & 37.8 & 56.6 \\
\hline Assessment makes students attentive in the classroom & 4082 & 1.8 & 3.2 & 5.7 & 47.3 & 42 \\
\hline Assessment makes students confident for their final examination & 4083 & 2.1 & 2.5 & 4.8 & 31.7 & 58.9 \\
\hline Assessment makes it difficult for teachers to cover the syllabus & 4077 & 38 & 32.3 & 9.2 & 15.3 & 5.2 \\
\hline Assessment has negligible impact on teaching and learning & 4073 & 45.9 & 24.6 & 9.2 & 13.3 & 6.9 \\
\hline $\begin{array}{l}\text { Assessment feedback is useful in enhancing students' } \\
\text { performance }\end{array}$ & 4081 & 2.3 & 2.6 & 2.9 & 33.1 & 59.2 \\
\hline Assessment increases the workload for teachers & 4067 & 19.4 & 25.8 & 8.4 & 29 & 17.4 \\
\hline Assessment should be conducted based on students' time & 4075 & 27.4 & 27.2 & 13.6 & 23.2 & 8.5 \\
\hline Assessment should be conducted based on teachers convenience & 4053 & 18.6 & 28.6 & 15 & 28.5 & 9.3 \\
\hline Assessment interferes teaching and learning & 4061 & 40.8 & 31.5 & 7.3 & 13.8 & 6.6 \\
\hline
\end{tabular}

Table IV shows that the statements "Assessment makes students concentrate their efforts in learning", "Assessment feedback is useful in enhancing students' performance" and "Assessment makes students confident for their final examination" were strongly agreed or agreed by a total of $94.4 \%, 92.3 \%$ and $90.6 \%$ of the respondents respectively. The statement "Assessment increases the workload for teachers" was strongly agreed or agreed by a total of 46.4 percent of teachers. This indicates that although teachers perceived assessment as important in enhancing performance, they regarded it as a burden in terms of their workload. Consequently, even the statement that "Assessment should be conducted based on teachers' convenience" was strongly agreed or agreed by a total of 37.8 percent of teachers. The statement that assessment has negligible impact on learning was strongly agreed or agreed by a total of 20.2 percent of the participants. Teachers with such kind of perception are unlikely to use assessment to identify strengths and weaknesses of their students so that they could take appropriate measures. Hence, they conduct assessment to fulfill accountability requirements only but they do not consider it as a vital tool to enhance teaching and learning.

\section{A. Gender Differences in Perceptions}

In order to establish gender differences, an overall perception of teachers on assessment was first computed The key for statements that were negatively worded was reversed and then the mean scores based on the total score of all the ten items was computed. The maximum possible score was 50 . The overall mean perception score was 38.7 with a standard deviation of 5.5 indicating that generally teachers who participated in the study held a positive perception of assessment.

The mean scores for male and female teachers were computed to determine whether there were gender differences in their perceptions. Table V presents the mean perception by female teachers had more favorable perceptions of assessment than their male counterparts.

TABLE V: TEACHERS' PERCEPTION BY GENDER

\begin{tabular}{lllll}
\hline \hline Gender & $\mathrm{N}$ & Mean & $\begin{array}{l}\text { Std. } \\
\text { Deviation }\end{array}$ & $\begin{array}{l}\text { Std. Error } \\
\text { Mean }\end{array}$ \\
\hline Female & 1107 & 39.1644 & 5.22393 & .15701 \\
Male & 2921 & 38.5317 & 5.60043 & .10362 \\
\hline \hline
\end{tabular}

In order to establish whether the observed differences in the mean perception score for male and female was statistically significant, an independent sample t-test was performed. The results of the t-test are presented in Table VI.

TABLE VI: GENDER DIFFERENCES IN TEACHERS' PERCEPTIONS

\begin{tabular}{lllll}
\hline \hline & & & & \\
& $t$ & df & $\begin{array}{c}\text { Sig. } \\
\text { (2-tailed) }\end{array}$ & $\begin{array}{l}\text { Mean } \\
\text { Difference }\end{array}$ \\
\hline $\begin{array}{l}\text { Equal variances } \\
\text { assumed }\end{array}$ & 3.260 & 4026 & .001 & .63274 \\
$\begin{array}{l}\text { Equal variances } \\
\text { not assumed }\end{array}$ & 3.363 & 2126.52 & .001 & .63274 \\
\hline
\end{tabular}

Results presented in Table VI shows that there is a statistically significant difference in teachers' perception of assessment by gender. The $t$-test indicates that female teachers had more favorable perceptions of assessment than male teachers. In terms of classroom practices, the finding suggests that female teachers tend to use assessment more often to facilitate and support teaching and learning than their male counterparts. It could be interesting to explore further whether revealed differences in perceptions of assessment also imply differences in the effectiveness of the teaching strategies used in enhancing learning outcomes of the students as well in utilizing assessment feedback to render the needed remedial assistance in order to close achievement gaps realized. 


\section{DISCUSSION AND CONCLUSION}

Findings of this study indicates that, generally, teachers have favorable perceptions of assessment. However, the view by 20.7 percent of teachers that the purpose of assessment is "to prepare students for their final examination" signifies the impact of high-stakes examinations on teaching and learning. Because of the pressure to reverse the declining trend in performance, teachers use assessment as a tool to prepare students to pass examinations rather than a tool to enhance teaching and learning. This view is reinforced by the fact that the statement "Assessment makes students confident for their final examination" was strongly agreed or agreed by a total of 90.6 percent of teachers who participated in the study

Teachers who participated in the study also indicated that they hold highly the motivational function of assessment. The statement "assessment makes students concentrate their efforts in learning" was either agreed or strongly agreed by a total of 94.4 percent of teachers. This high degree of agreement shows that teachers appreciate the role of assessment in motivating students to learn. In that case, if the assessment tasks used in the classrooms are meaningful, they are likely to improve learning outcomes of students through formation of appropriate study habits.

With regard to the usefulness of assessment feedback in enhancing students' performance, a total of 92.3 percent of teachers strongly agreed or agreed to the statement. Teachers' with this kind of perception are likely to use assessment to guide the teaching and learning of their students. On the other hand, teachers who consider assessment as intended to generate marks for reporting purposes are treating assessment in isolation from teaching and learning. They are unlikely to use assessment feedback to design remedial measures for students because for them using assessment for reporting purpose is more important than using it in facilitating teaching and learning.

Despite the fact that teachers reported favorable perceptions of assessment, they seem to be facing a conflict in implementing effective assessment in their classrooms. The statements "assessment increases the workload of teachers" and that "assessment should be conducted based on teachers convenience" were either agreed or strongly agreed by over 30 percent of teachers. This means that although teachers acknowledge the importance of assessment, they consider it as an additional load to their work. Their responses tend to suggest that assessment should be done at their convenience rather than being grounded from the importance and need for obtaining useful feedback for each milestone of teaching and learning. Such perceptions may be influenced the fact that some teachers have heavy teaching loads making it difficult for them to conduct meaningful assessment and offer regular feedback to the students.

This study was limited by the fact that it has relied exclusively on the reported perceptions of teachers. It is likely that there is mismatch between what is being reported and what is actually practiced. Future studies could establish a relationship between perceptions and assessment practices. It could also be important to explore challenges that teachers are facing in implementing classroom assessment and render them necessary support so that they can use effective assessment methods in enhancing teaching and learning.
In-service training programmes that focus on the role of classroom assessment are essential to equip teachers with necessary skills for assessing their students and also to make them appreciate the role of assessment rather than considering it as an additional workload.

\section{REFERENCES}

[1] A. J. Nitko and S. M Brookhart, Educational Assessment of Students, 5th ed., Upper Saddle River, NJ: Merril, 2007, p. 4.

[2] T. A. Angelo and P. K. Cross, Classroom Assessment Techniques: A Handbook for College Teachers, 2nd ed., San Francisco: Jossey-Bass, 1993, pp. 3-7.

[3] M. B Huba and J. E Freed, Learner-centered assessment on college campuses: Shifting the focus from teaching to learning, Boston: Allyn and Bacon, 2000, ch. 1.

[4] W. J. Popham, Classroom Assessment: What Teachers Need to Know, 5th ed., Boston: Allyn and Bacon, 2008, pp. 12-16.

[5] L. Agrey. (Spring, 2004). The Pressure Cooker in Education: Standardized Assessment and High-Stakes. Canadian Social Studies. [Online]. 38(3). Available: http://www.quasar.ualberta.ca/css.

[6] R. Linn and N Gronlund, Measurement and Assessment in Teaching, 8th ed., Upper Saddle River, NJ: Merrill, 2000.

[7] R. J. Stiggins. "High quality classroom assessment. What does it really mean?" Educational Measurement: Issues and Practices, vol. 11, no. 2, pp. 35-39, June 1992.

[8] P. Black and D. William. "Inside the black box: Raising standards through classroom assessment," Phi Delta Kappan, vol. 80, no. 2, pp. 139-148, October, 1998

[9] R. J. Stiggins, J. A. Arter, J. Chappuis, and S. Chappuis, Classroom assessment for student learning: Doing it right - using it well, Princetown, NJ: Educational Testing Service, 2006, pp. 3-40.

[10] P. Black and D. Wiliam, "Assessment and classroom learning," Assessment in Education, vol. 5, no. 1, pp.7-74, 1998.

[11] P. W. Airasian, Classroom assessment: Concepts and applications, New York: McGraw-Hill, 2001.

[12] R. J Stiggins and J. Chappius, "Using Student-involved classroom to close achievement gaps," Theory into Practice, vol. 44, no. 1, pp. 11-18, 2005.

[13] H. J. Borko and R. Putnam, "Learning to teach," in D. C. Berliner and R. C. Calfee (Eds.)," Handbook of educational psychology, part 6, pp. 673-709. New York: MacMillan, 1996.

[14] G. T. Brown, "Teachers' conception of assessment: validation of an abridged instrument," Psychological Reports, vol. 99, no. 1, pp. 166-170, August 2006.

[15] C. Danielson, Assessment for learning: for teachers as well as students. In C. A. Dwyer (Ed.), The future of assessment: Shaping teaching and learning, New York: Taylor \& Francis, pp. 191-213, 2008.

[16] Assessment Reform Group, Assessment for Learning: beyond the black box, Cambridge: University of Cambridge School of Education, 1999.

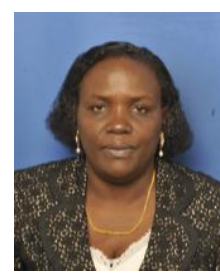

Joyce L. Ndalichako holds a bachelor of education with mathematics as a major subject conferred by the University of Dar es Salaam in 1991. In 1997 she obtained a $\mathrm{PhD}$ in educational measurement and evaluation granted by the University of Alberta, Canada. Her research interests include the role of classroom assessment, learning difficulties and misconceptions experienced by students, and the use continuous assessment.

She is currently an associate professor in assessment, measurement and evaluation at the Aga Khan University. She was the executive secretary of the National Examinations Council of Tanzania (NECTA) from July 2005 to August 2014. Prior to her appointment as an executive secretary of NECTA she taught at the University of Dar es salaam for 15 years. The courses taught at undergraduate and postgraduate levels included: educational statistics, measurement and evaluation, assessment in education and Research methods. She has several publications in the areas of assessment, educational statistics and learning difficulties faced by students.

Prof. Ndalichako is a member of the Association for Educational Assessment in Africa, the National Council on Measurement and Evaluation, International Association for Educational Assessment, and the American Educational Research Association. 